\title{
The Effect of Foreign Exchange Reforms on Financial Deepening: Evidence from Nigeria
}

\author{
Ani W. $\mathrm{U}^{1}$, Ugwunta D. $\mathrm{O}^{2}$, and Okanya $\mathrm{O}^{3}$ \\ ${ }^{I}$ Department of Banking and Finance, Michael Okpara University ofAgriculture, Umudike, Abia State, Nigeria \\ ${ }^{2}$ Department of Banking Finance, Renaissance University Ugbawka Enugu State, Nigeria \\ ${ }^{3}$ Institute of Management and Technology, Enugu
}

\begin{abstract}
The peculiarity of the Nigerian economy makes exchange rate management critical to the overall wellbeing of the economy. In particular, Nigeria's mono-economy with its very high dependence on commodities export and high penchant for imported goods exposes the economy to the vagaries of the international foreign exchange market. Nigeria has witnessed about fifteen distinct foreign exchange reform episodes from 1962 to date with mixed outcomes on the economy of the nation in general and financial depth in particular. This paper therefore evaluates the overall effect of foreign exchange reforms on the financial depth of the Nigerian economy over a twenty -nine year period. The explanatory variables were developed and selected in line with theoretical framework. Having certified that the time series are free of unit root, OLS regressions were applied to the data to determine the overall effect of foreign exchange reforms on the financial depth of the economy. Findings of the resulting times series analysis shed considerable light on the degree, dimension and direction of the determinants of financial depth. First the ratio of FDI to GDP, ratio of market capitalization of listed equities to GDP and real interest rate have positive relationship with financial deepening while exchange rate has a negative relationship with financial deepening. Secondly, among the determinants of financial depth only the ratio of GDP to real interest rates posted a significant relationship with foreign exchange. Overall, the evidence from the non-spurious regression results suggest that foreign exchange reforms in Nigeria have not had the desired positive effect on the depth of the Nigerian financial sector. The paper therefore recommends strong diversification of the Nigerian economy away from the mono-economy and its peculiarities into other non-oil sectors so as to enhance commodities export and reap the benefits of stable exchange rate.
\end{abstract}

Key Words: FDI, foreign exchange reforms, financial deepening, gross domestic product, bank assets

\section{Introduction}

Transactions in the foreign exchange constitute an important aspect of financial sector activities and arguably it is the largest and most extensive financial market in the world (Anyafo, 1996). This is because apart from being the vehicle for settlement of international transactions, it functions as the medium of interaction between sellers and buyers of foreign exchange in a bid to negotiate a mutually acceptable price for the promotion and furtherance of international transactions.

The financial sector is hugely affected by activities in the foreign exchange market primarily because of the central role of banks in financial intermediation. Furthermore the peculiarity of the Nigerian economy makes exchange rate management critical to the overall wellbeing of the economy. In particular, Nigeria's mono-economy with its very high dependence on commodities export and high penchant for imported goods exposes the economy to the vagaries of the international foreign exchange market. The supply of foreign exchange in Nigeria comes in diverse ways including oil exports, non-oil exports, capital receipts including draw-down on loans, expenditure of foreign tourists in Nigeria, repatriation of capital by Nigerians resident abroad, and other invisible receipts by the private sector. The demand for foreign exchange on the other hand covers payments for imports, external debt service obligations and financial commitments to international organizations. This scenario tasks the dexterity and financial adroitness of the nations' financial managers to achieve efficiency in foreign exchange management and thus further the frontiers of the nation's economy. For this reason foreign exchange market reforms have always enjoyed a prominent place in the overall reform template of the financial sector in Nigeria. The attention recently placed on the reform of the financial sector is hinged among other things on its ability to achieve financial deepening in the economy.

ISSN 2167-9606 Print/ ISSN 2167-9614 Online/ World Scholars http://www.worldscholars.org 
Nigeria has witnessed about fifteen distinct foreign exchange reform episodes from 1962 to date with mixed outcomes on the economy of the nation in general and financial depth in particular. This seems to agree with a recent World Bank report that financial deepening is poor indeveloping countries. The report gave reasons for this poor showing to include the low level of foreign direct investments, shallow capital market, distortions in interest rate, and weak association between financial openness and financial deepening. Empirical literature concerning financial liberalization and foreign exchange management abounds while literature concerning reforms in the Nigerian exchange rate reforms are still scanty. This is the gap that this empirical study intends to fill. This paper therefore evaluates the overall effect of foreign exchange reforms on the financial depth of the economy with the aim of determining whether foreign exchange reforms in Nigeria have had the desired positive effect on the depth of the Nigerian financial sector.

\section{Literature review}

With the view of stabilizing exchange rate for the naira various techniques have been introduced by the Nigerian monetary authorities in the management of foreign exchange rate. Okafor (2011) averred that the determination of the monetary authorities to contain persistent depreciation and fluctuations of the naira informed the frequency with which the management techniques were introduced. Numerous variants of market determined exchange rates have been adopted since 1986 in a bid to stabilize the rates as well as ensure a single exchange rate for the naira. CBN (2013) noted that in 1986, the Second-tier Foreign Exchange Market (SFEM) was instituted, in 1987, the Unified Official Market was introduced, and in 1999, the Inter-bank Foreign Exchange Market (IFEM) was introduced. According to this CBN report, in a quest to enhance access to foreign exchange to small users and to enlarge the foreign exchange market in Nigeria, the monetary authorities licensed the Bureaux de Change in 1989. Okafor (2011) pointed out that scarcity and bureaucratic procedures in the official sector enhanced the development and growth of the parallel market sector. Also, the increasingly demand for foreign exchange at a period when the supply of foreign exchange was dwindling enhanced the development of the foreign exchange parallel market.

CBN (2013) noted that the changing pattern of international trade, institutional changes in the economy and structural shifts in production are the chiefly factors that have influenced the development of the Nigeria foreign exchange market. Access to foreign exchange by the private sector before the establishment of the Central Bank of Nigeria (CBN) in 1958 and the consequent enactment of the Exchange Control Act of 1962 were made possible by commercial banks which maintain balances abroad and acted as agents for local exporters. In this era, agricultural exports contributed the bulk of foreign exchange receipts. This scenario was operational because of the convertibility ease accorded to the Nigerian pound by the British pound given that the Nigerian pound was tied to the British pound sterling at par. This process actually delayed the development of an active foreign exchange market in Nigeria but with the establishment of the Central Bank of Nigeria (CBN) in 1958 and the subsequent centralisation of foreign exchange authority in the CBN, the need to develop a local foreign exchange market was ignited.

Further reforms were introduced in the Foreign Exchange Market in 1994 (CBN, 2013). CBN (2013) noted that the Foreign Exchange Market reform of 1994 include the formal pegging of the naira exchange rate, the centralisation of foreign exchange in the CBN, the restriction of Bureaux de Change to buy foreign exchange as agents of the CBN, the reaffirmation of the illegality of the parallel market and the discontinuation of open accounts and bills for collection as means of payments sectors. Further reforms narrowed down to the liberalization of the Foreign Exchange Market in 1995 with the consequent introduction of an Autonomous Foreign Exchange Market (AFEM) for the sale of foreign exchange to end-users by the monetary authority through selected authorised dealers at market determined exchange rate. Additionally, Bureaux de Change institutions were once more accorded the status of authorized buyers and sellers of foreign exchange. The Foreign Exchange Market was further liberalized in October, 1999 with the introduction of an Inter-bank Foreign Exchange Market (IFEM) (CBN, 2013). Futhermore the retail Dutch Applied System was introduced. Under this system, end users made bids through authorized dealers who acted as intermediaries in the bidding process. Again in 2006, the wholesale DAS was introduced. This system recognized authorised dealers as principal and not agents. They were then expected to sell to their customers at a permitted margin (Anyafo,1999)

Limited empirical work have been carried out by researchers seeking to understand the relationship between foreign exchange and bank efficiency in various climes.

For instance, Owoeye and Ogunmakin (2013) using two proxies for bank performance (loan loss to total advances ratio and capital deposit ratio) examined the impact of unstable exchange rate on bank performance in Nigeria. Their specified models 
suggest that the impact of exchange rate on bank performance is sensitive to the type of proxy used to capture bank performance. Loan loss to total advance ratio shows that fluctuating exchange rate may affect the ability of lenders to manage loans resulting into high level of bad loans while capital deposit ratio does not have significant relationship with exchange rate.

In another work, Omojimite and Akpokodje (2010) investigated the effect of exchange rate reforms on Nigeria's trade performance during the period 1986-2007. The study found a minimal positive effect of exchange rate reforms on non-oil exports through the depreciation of the value of the country's currency. It was also found that the structure of imports which is pro-consumer goods remained unchanged even after the adoption of exchange rate reforms. Exchange rate reforms were found not to constrain imports as anticipated. Rather, they stimulate imports, albeit insignificantly. These authors suggest that exchange rate reforms are not sufficient to diversify the economy and change the structure of imports while Bakare (2011) supports the replacement of the floating exchange regime while adopting purchasing power parity which has been considered by past studies to be more appropriate in determining realistic exchange rate for naira and contribute positively to macroeconomic performances in Nigeria.

Ettah et al (2011) focused on the effects of price and exchange rate fluctuations on Agricultural exports (cocoa) in Nigeria. Data were applied to an export supply function for cocoa specified and estimated using the Ordinary Least Squares Regression. Results showed that exchange rate fluctuations and agricultural credits positively affect cocoa exports in Nigeria. Results also revealed that relative prices of cocoa are insignificantly related to quantity of export. Their result therefore, implied a positive significant effect of exchange rate volatility on cocoa exports in Nigeria. They recommend that agricultural credit schemes should be restructured in a way that should meet the needs of farmers; and such credit facilities should be made available and accessible to cocoa farmers in order to boost their production capacity while there should be a free market determination of exchange rate for export of cocoa in Nigeria.

\section{Methodology}

The research was designed to examine the effect of foreign exchange reforms on financial deepening in Nigeria from 1982 to 2009.An ex post facto research design was used for the twenty nine years study period thus qualifying it as a times series study. Asika (2005) underscored the importance of ex post facto research by pointing out that such research provides a systematic and empirical solution to research problems, by using data which are already in existence. Again, though the data are not subject to control or manipulation, since they already exist, yet the researcher can contrive or create a situation that will generate the requisite data for analysis. Most importantly the outcome of the analysis can provide considerable insight into future outcomes.

The variables used in the study and the model specification were based on established theoretical relationships, their use in previous studies and the availability of useable data. The multi-linear relationship specified below was used to shed light on the effect of foreign exchange reforms in Nigeria and financial deepening.

\section{Sources of data}

Data relating to Exchange rate reforms were sourced from the Central Bank of Nigeria's statistical bulletin. Data pertaining to the various proxies of financial deepening were equally sourced from Central Bank of Nigeria's statistical bulletin and the apex bank's Annual reports.

\section{Research variables}

The following metrics were used for the dependent and independent variables.

\section{Dependent Variables}

The dependent variable in this study is financial deepening. According to Mohan (2005), the financial depth of an economy is derived by relating the key macroeconomic indices of financial sector operations to the gross domestic product. The major banking sector aggregates which impact significantly on financial deepening are total banking sector assets (BA), total demand deposits (DD) and total loans and advances (LAD). According to Okafor (2011), the absolute levels of the three aggregates relative to the GDP present very concise measures of financial deepening. Accordingly, bank assets to GDP ratio (BA ratio), bank deposits to GDP ratio (BD ratio) and loans and advances to GDP ratio (BL ratio) were used to proxy financial deepening. While the first metric was used as the primary proxy the subsequent ones were used as robustness checks on the study. The applicable notations are set below:

BA ratio= Bank Assets /Gross Domestic product........1 $\mathrm{BD}$ ratio $=$ Bank Deposits /Gross Domestic product....2 $\mathrm{BL}$ ratio $=$ Bank loans and advances /Gross Domestic Product 


\section{Independent Variable (The Test Variable)}

The independent variable (the test variable) in this study is foreign exchange reforms. This was measured as the prevailing exchange rate at year end between the Naira and the US Dollar from 1982 to 2010.

Foreign exchange reforms $=$ Exchange rate $\mathrm{N}: \$$ at year end ........................................ 4

\section{Control Variables (Explanatory Variables)}

The variables listed below which are theoretically recognized determinants of financial deepening were used a control variables. These variables are foreign direct investments, capital market and interest rates.

The $\log$ transformations of these aggregate variables werepreferred to enable this metric fit into the linear model to be tested. The notations are as follows:

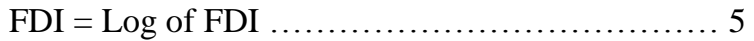
CAPMKT $=$ Market capitalization of listed equity--- 6 Interest Rate $=$ Interest rate per year............... 7

\section{Model Specification}

According to Koutsoyiannis (2003), model specification involves the determination of the dependent and explanatory variables which will be included in the model, the theoretical expectations about the sign and the size of the parameters of the function. To examine the effect of foreign exchange reforms on financial deepening in Nigeria, key determinants of financial deepening were identified and modeled in multiple linear regression form specified in the symbolic form of:

FIDEEPt. $=f($ FOREX, FDI, CAPMKT, INTRATE $)$ $\mathrm{t}$............................................. 8

Where FINDEEPt $=\mathrm{BA}$ ratio, $\mathrm{BD}$ ratio, and $\mathrm{BL}$ ratio of aggregate economy in time $t$, respectively. The model was estimated on three separate sets of regressions using (a). BA ratio as a dependent variable, (b) BD ratio as a dependent variable and (c) $B L$ ratio as a dependent variable.

When expressed as an additive function, the relationship above may be translated into a multiple equation as follows:

FINDEEPt $=\beta o+\beta_{1} \gamma 1_{t}+\beta 2 \gamma 2_{t}+\beta 3 \gamma 3_{t}+\beta 4 \gamma 4_{t}+e_{t}$ 9

Using the various definitions of the dependent variable, the additive function is further expressed as follows.

BA ratio $(t)=\beta o+\beta_{1} \gamma 1 t+\beta 2 \gamma 2 t+\beta 3 \gamma 3 t+\beta 4 \gamma 4 t+$ e.........................................10

BD ratio $(t)=\beta o+\beta_{1} \gamma 1 t+\beta 2 \gamma 2 t+\beta 3 \gamma 3 t+\beta 4 \gamma 4 t+$

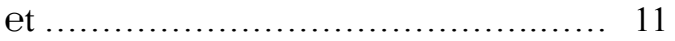

$\mathrm{BL}$ ratio $(\mathrm{t})=\beta \mathrm{o}+\beta_{1} \gamma 1 \mathrm{t}+\beta 2 \gamma 2 \mathrm{t}+\beta 3 \gamma 3 \mathrm{t}+\beta 4 \gamma 4 \mathrm{t}+$ et ....................................... 12

Where

Bo $=$ unknown intercept.

$\gamma 1=$ FOREX

$\gamma_{2}=$ FDI

$\gamma_{3}=$ CAPMKT

$\gamma_{4}=$ INTRATE

$\beta_{1, \text { etc }}=$ measure of the contribution of $\gamma$ in the model.

\section{Results}

The time series data used to determine the effect of foreign exchange reforms on financial deepening were generated from the Central Bank of Nigeria statistical bulletin. The properties of the time series were firstly checked for unit root problems using the Augmented Dicky Fuller test statistic and the result of the test are presented in table 1 below.

Table 1.ADF Unit Root Test Result.

\begin{tabular}{|c|c|c|c|c|c|}
\hline V a r i a b l e & $1 \%$ critical value*@level & ADF Test statistic @ level & Status & 1\% critical value*@ & ADF Test Statistic (t*) \\
\hline $\begin{array}{llllll}R & B & A & G & D & P \\
\end{array}$ & 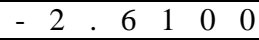 & $\begin{array}{llllll}0 & 4 & 7 & 7 & 2 & 9\end{array}$ & $1 \quad(1)$ & $\begin{array}{llll}6 & 1 & 1 & 0 \\
\end{array}$ & $\begin{array}{llllll}2 & 4 & 4 & 1 & 1 & 1 \\
\end{array}$ \\
\hline $\begin{array}{llllll}R & B & D & G & D & P\end{array}$ & $\begin{array}{llll}6 & 1 & 0 & 0\end{array}$ & 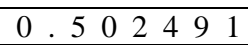 & $1(1)$ & $\begin{array}{llll}6 & 1 & 1 & 0\end{array}$ & $\begin{array}{llllll}1 & 3 & 2 & 5 & 5 & 4\end{array}$ \\
\hline R B L A G D P & $\begin{array}{llll}6 & 1 & 0 & 0 \\
\end{array}$ & 0.349432 & $1(1)$ & $\begin{array}{llll}6 & 1 & 1 & 0 \\
\end{array}$ & $\begin{array}{llllll}7 & 5 & 1 & 4 & 7 & 6 \\
\end{array}$ \\
\hline E X C H R A T E & $\begin{array}{llll}6 & 4 & 8 & 6\end{array}$ & -0.951031 & $1 \quad(1)$ & $\begin{array}{llll}6 & 5 & 2 & 2\end{array}$ & $\begin{array}{llllll}8 & 9 & 5 & 8 & 3 & 7\end{array}$ \\
\hline $\begin{array}{lllllll}R & F & D & I & G & D & P\end{array}$ & $\begin{array}{llll}6 & 0 & 6 & 7 \\
\end{array}$ & -2.168287 & $1(1)$ & $\begin{array}{llll}6 & 2 & 4 & 3 \\
\end{array}$ & $\begin{array}{llllll}9 & 7 & 5 & 7 & 1 & 8 \\
\end{array}$ \\
\hline R I N T R A T E & $\begin{array}{llll}6 & 2 & 2 & 7 \\
\end{array}$ & -4.054012 & $1(0)$ & $\ldots-\cdots$ & $\begin{array}{lllllll} & - & - & - & - & - & -\end{array}$ \\
\hline R M K T G D P & $\begin{array}{llll}6 & 1 & 0 & 0\end{array}$ & -0.492091 & $1(1)$ & -7.206083 & $\begin{array}{llll}6 & 1 & 1 & 0\end{array}$ \\
\hline
\end{tabular}

Where:

RBAGDP $=$ Ratio of Bank Assets to GDP

RBMGDP $=$ Ratio of Broad Money (M2) to GDP

RBLAGDP $=$ Ratio of Bank Loans and Advances to

GDP

EXCHRATE $=$ Exchange Rate
RFDIGDP $=$ Ratio of Foreign Direct Investment to GDP

RINTRATE $=$ Real Interest Rate

RMKTGDP = Ratio of Market Capitalization to GDP. 
The table above presents the ADF unit root test which shows that the ratio of bank assets to GDP; ratio of bank deposit to GDP; ratio of bank loans and advances to GDP; exchange rate; ratio of FDI to GDP and ratio of market capitalization to GDP having unit root problems as their ADF test statistics at level > the $1 \%$ critical value at level ie not been stationary at level. Real interest rate was stationary at level. However, by differencing, the non-stationary time series became stationary at $1^{\text {st }}$ difference as their $1 \%$ critical values > ADF test statistic and hence the nonspurious regression results below.

Table 2.Least Squares Regression Results.

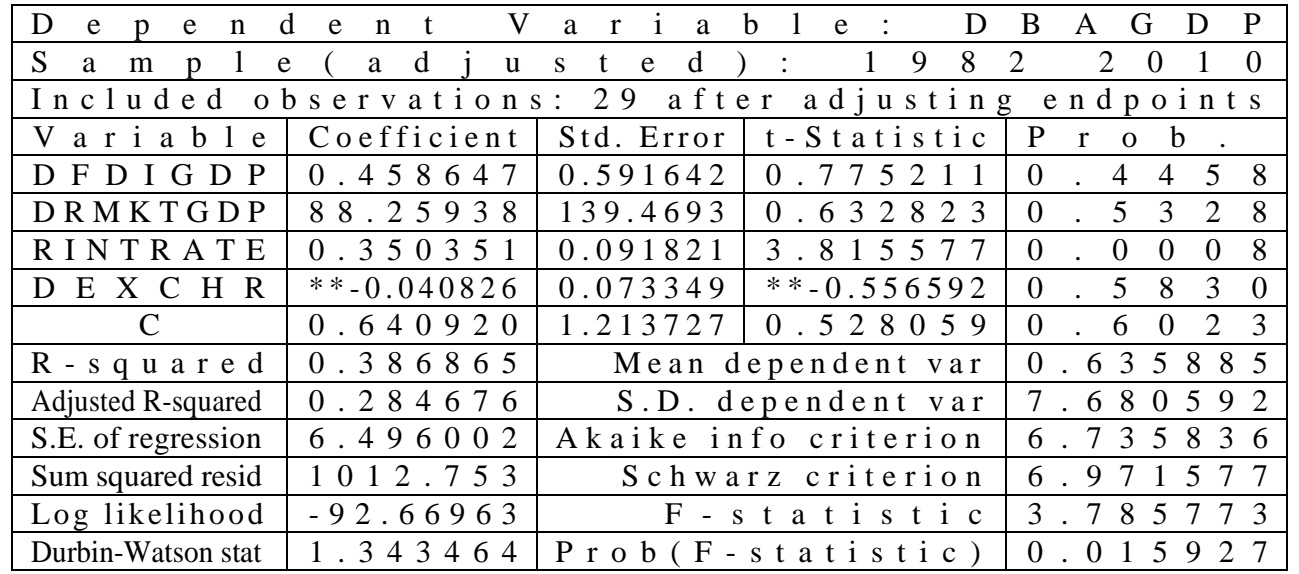

After adjusting for endpoints, the time period was truncated to 29 years from 1982 to 2010 due to nonavailability of certain variables (exchange rate, FDI, market capitalization and real interest rate) before 1982. The adjusted coefficient of multiple determination shows that the $28.46 \%$ of the variations in the dependent variable, financial deepening were explained by our model. At Fstatistic of $3.78 \%$ our model is significant as the prob(F-statistic) of $0.0159<0.05$ significant value.

A look at the table also reveals that the ratio of FDI to GDP, ratio of market capitalization of listed equities to GDP and real interest rate have positive relationship with financial deepening while exchange rate have a negative relationship with financial deepening. The overall regression result suggests that foreign exchange reforms in Nigeria have not have a positive effect on financial deepening as measured by the ratio of bank assets to GDP. The regression results of the robustness tests however presented mixed results. While financial deepening as proxied by the ratio of broad money (M2) to GDP shows a positive relationship with foreign exchange reforms, financial deepening as measured by the ratio of bank loans and advances to GDP presents a negative relationship with foreign exchange reform (tables $3 \& 4$ ).

Table 3.Least Squares Regression Results.

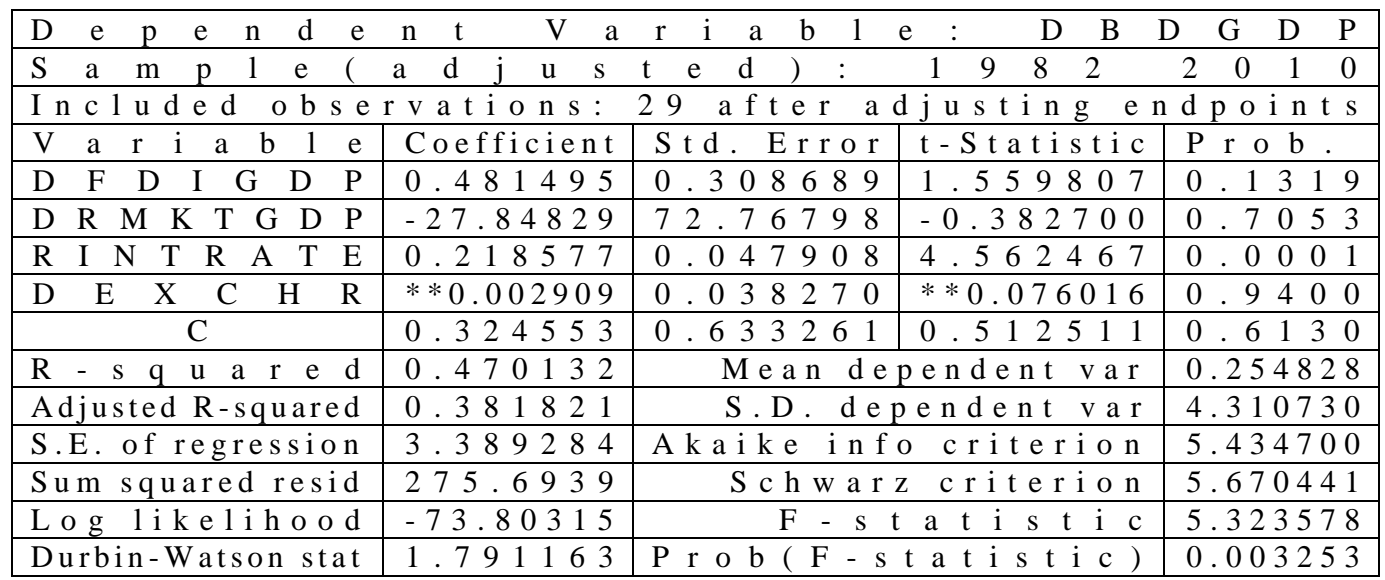


Table 4.Least Squares Regression Results.

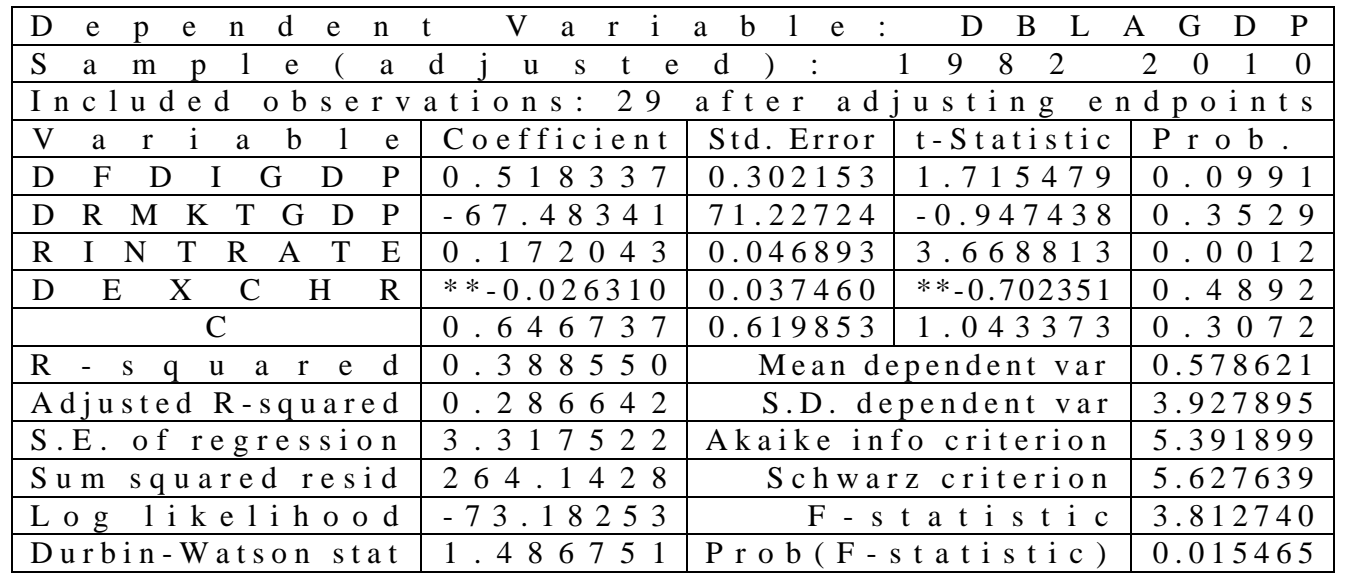

\section{Conclusion and Recommendations}

Given that the financial sector is hugely affected by activities in the foreign exchange market primarily because of the central role of banks in financial intermediation, and that exchange rate management is critical to the overall wellbeing of the Nigerian economy, this paper has analytically examined the effect of foreign exchange reforms on the depth of financial activities in Nigeria. Overall, the evidence from the nonspurious regression results suggest that foreign exchange reforms in Nigeria have not have the desired positive effect on the depth of the Nigerian financial sector. It is strongly argued that financial liberalization can have strong positive effects on economic performance. This implies that after the prescribed exchange rate reforms, the domestic economy has failed to experience impressive performance such as a stable exchange rate capable of attracting foreign investment or halt capital flight. Nigeria's currency have consistently failed to measure up in terms of value appreciation with other currencies in the international market. Generally, our findings suggest that reforms in the financial services sector generates tremendous financial booms and busts in the short-run, but these booms and busts have not intensified in the long-run.

The paper therefore recommends strong diversification of the Nigerian economy away from the mono-economy and its peculiarities into other non-oil sectors so as to enhance commodities export and reap the benefits of stable exchange rate. There should be strong incentives for value added most especially for agricultural exports to contribute significantly to the bulk of foreign exchange receipts.
This will boost export and thus enhance favorable balance of trade as well as payment and limit the exposure of the economy to the vagaries and fluctuations of the international foreign exchange market.

\section{Rreferences}

Anyafo, (1999). Nigerian Financial Market and Institutions, Enugu, Banking and Finance Publications.

Asika, N (2005): Research Methodology in the Behavioural Sciences, Lagos: Longman.

Bakare A.S. (2011), "The Consequences of Foreign Exchange Rate Reforms on the Performances of Private Domestic Investment in Nigeria" International Journal of Economics and Management Sciences Vol. 1, No. 1, pp. 25-31

CBN, (2013), "The Foreign Exchange Market in Nigeria" Retrieved from: http://www.cenbank.org/IntOps VFXMarket.asp

Ettah, B.E., Akpan, O.D. \& Etim, R.S. (2011) Effects of Price and Exchange Rate Fluctuations on Agricultural Exports in Nigeria, International Journal of Economic Development Research and Investment, Vol. 2 No. 1

Koutsonynanis, A (2003): Theory of Econometrics, $2^{\text {nd }}$ ed. London: PalgravePublishers.

Mohan, R. (2005) "Financial Sector Reforms: Policies and Performance Analysis", Economic Political Weekly, Special issue on Money, Banking and Finance, March 40 pp 11061121.

Okafor, F.O. (2011) 50 years of Banking Sector Reforms in Nigeria (1960-2010) Past Lessons: Future imperatives, Enugu, Ezu books limited.

Omojimite, B. U. and Akpokodje A. (2010) "The Impact of Exchange Rate Reforms on Trade Performance in Nigeria, $J$ SocSci, 23 (1): 53-62.

Owoeye, T. \& Ogunmakin A. A. (2013), Exchange Rate Volatility and bank Performance in Nigeria Asian Economic and Financial Review, 3(2):178-185. 